\title{
Wastewater Treatment Plants as Local Thermal Power Stations-Modifying Internal Heat Supply for Covering External Heat Demand
}

\author{
Florian Kretschmer ${ }^{1, *(D)}$, Bernd Hrdy ${ }^{1}$, Georg Neugebauer ${ }^{2}(\mathbb{D})$ and Gernot Stoeglehner $^{2}(\mathbb{D})$ \\ 1 University of Natural Resources and Life Sciences, Vienna, Department of Water, Atmosphere and \\ Environment, Institute of Sanitary Engineering and Water Pollution Control, Muthgasse 18, \\ 1190 Vienna, Austria; bernd.hrdy@boku.ac.at \\ 2 University of Natural Resources and Life Sciences, Vienna, Department of Landscape, Spatial and \\ Infrastructure Sciences, Institute of Spatial Planning, Environmental Planning and Land Rearrangement, \\ Peter-Jordan-Straße 82, 1190 Vienna, Austria; georg.neugebauer@boku.ac.at (G.N.); \\ gernot.stoeglehner@boku.ac.at (G.S.) \\ * Correspondence: florian.kretschmer@boku.ac.at
}

check for updates

Citation: Kretschmer, F.; Hrdy, B.; Neugebauer, G.; Stoeglehner, G. Wastewater Treatment Plants as Local Thermal Power Stations-Modifying Internal Heat Supply for Covering External Heat Demand. Processes 2021, 9, 1981. https://doi.org/ $10.3390 /$ pr9111981

Academic Editors: Giovanni Nicoletti, Roberto Bruno and Piero Bevilacqua

Received: 17 September 2021

Accepted: 23 October 2021

Published: 6 November 2021

Publisher's Note: MDPI stays neutral with regard to jurisdictional claims in published maps and institutional affiliations.

Copyright: (c) 2021 by the authors. Licensee MDPI, Basel, Switzerland. This article is an open access article distributed under the terms and conditions of the Creative Commons Attribution (CC BY) license (https:/ / creativecommons.org/licenses/by/ $4.0 /)$.

\begin{abstract}
To counteract climate change, the application of renewable energy sources and their efficient use are of crucial importance. In this context, wastewater has also gained increased attention in recent years. For decades, wastewater treatment plants have applied the heat from digester gas combustion to supply internal demands. However, in the context of efficient energy use the question arises: can using high temperature heat for supplying low temperature demand still be considered the best option? This article presents an innovative approach to covering wastewater treatment plant (WWTP) internal demand with low temperature wastewater heat recovery, making thermal energy from digester gas combustion available for feed-in to a local high temperature district heating network. The presented feasibility study was carried out in an Austrian municipality and investigates the heat balance, the economic risk, climatic benefits and the social aspects of the suggested approach. The practical implementation of the novel approach was planned in two steps. First, the WWTP should be connected to the district heating network to enable the feed-in of excess heat. Second, the WWTP internal heat supply should be modified and based on wastewater heat recovery from the effluent. Due to the promising results of the feasibility study, the first step was realized in summer 2020. The second and final step was initiated in 2021.
\end{abstract}

Keywords: integrated energy and spatial planning; renewable heat supply; wastewater heat recovery; district heating; digester heating

\section{Introduction}

Climate change is one of the great challenges of our times. Efficient energy usage and the substitution of fossil energy sources by renewable ones are considered key principles to counteract global warming (European Commission [1]). Recently, related measures are also gaining importance in the wastewater sector, although the main purposes of the wastewater infrastructure (sewer systems, wastewater treatment plants) has been and will remain ensuring public health and community hygiene, (surface and ground-) water pollution control, and urban (pluvial) flood protection. However, as the tasks of wastewater collection and treatment can be rather energy demanding, activities to optimize energy consumption already have a long tradition in this field (Gandiglio et al. [2]). However, to date, the main driver for related activities appears to be the reduction of energy costs rather than any climate protection ambitions. In this context, achieving the highest possible degree of electric energy self-sufficiency usually has been the supposed objective at many wastewater treatment plants (WWTPs). The reason for this singular focus can be found in the fact that electricity generation at WWTPs has always been rather limited while thermal 
energy (heat) has often been available in excess (Kretschmer et al. [3]). This applies, above all, for WWTPs with anaerobic sewage sludge treatment, where the produced digester gas/biogas has been used for the generation of electric and thermal energy by combined heat and power (CHP) units for decades (Elías-Maxil et al. [4]). Furthermore, previous activities have primarily addressed the WWTP specific (internal) energy demand and provision (where appropriate), without taking into account the (external) circumstances of the adjacent settlement structures. In other words, WWTPs have been considered more as an "energetic island" than as being part of a local energy system to date.

In recent times, however, one can observe a shift in the traditional view on wastewater. From a more general perspective, Kehrein et al. [5] postulate that wastewater can no longer be seen as waste due to the possibility of recovering water, energy, fertilizers and other valuables, and also providing a related overview on market supply potentials, related technologies and bottlenecks [6]. Puyol et al. [7] argue in a similar direction, discussing biological technologies for resource recovery from wastewater (e.g., biofuels, biopolymers). In a more specific context, the energetic view on a WWTP is moving from a previously rather isolated and electricity-centered perspective towards an integrated perspective that considers different types of (renewable) electric and thermal energy sources, as well as the local circumstances beyond the premises of a WWTP. Schäfer et al. [8], as well as Lichtenwoehrer et al. [9], investigate the possible role of WWTPs in regard to sector coupling, the former from an electricity-centered perspective, and the latter from a heatcentered perspective. Neugebauer et al. [10] investigate the spatial context between WWTPs (heat supply point) and their surrounding settlement structures (heat demand points). Spriet et al. [11] further elaborate these spatial analyses by also introducing a temporal perspective of heat supply and demand. Concerning wastewater-borne energy supply, Frijns et al. [12] postulate that wastewater actually contains two types of energy: not only the chemical one, bound in the form of organic contents, which can be made accessible through biogas from anaerobic digestion; but also the thermal one from hot/warm water usage, which can be recovered through heat exchangers situated in the (treated) wastewater stream in combination with heat pumps. In this context, Hao et al. [13] highlight the special relevance of thermal energy as the recoverable amount exceeds the chemical one by a factor 6 to 8 . Kretschmer et al. [3] argue in the same way and present comparable figures. Nielsen et al. [14] consider wastewater an unconventional excess heat source, which could play a viable role in local heat supply. Nagpal et al. [15] provide an overview on the benefits and challenges of wastewater heat recovery at different locations in the wastewater system (e.g., in-building, in-sewer, and in-effluent of a WWTP). Yang et al. [16] investigate the energy balance of WWTPs, considering different options for energy generation; namely sludge incineration, photovoltaics, and, here as well, wastewater heat recovery. They conclude that to balance the future energy system of WWTPs, a combination of energy sources need to be taken into account. Nakkasunchi et al. [17] present an overview on tools and options to support the decarbonization of the wastewater sector. They also emphasize the integration of energy savings, efficiency and the application of renewable energy generation technologies.

Concluding the above, one can say that the current research clearly demonstrates the high potential of activating and integrating different sources of renewable energy, not only for the wastewater sector. Therefore, it appears well comprehensible that the recast of the European Directive on the promotion of the use of energy from renewable sources [18] now also recognizes wastewater as a renewable source of energy. However, counteracting global warming does not only concern the best possible exploitation of renewable energy sources, but also the most efficient use of energy. Almost 10 years ago, Seibert-Ehrling [19] postulated a differentiated view on the energy sources available at a WWTP considering their energetic state, exergy and anergy. Starting from this idea, one should scrutinize the recent practice of applying biogas from anaerobic digestion in CHP units to supply WWTP internal heat demand. Here the critical question arises as to whether it is still a contemporary solution to cover the low temperature heat demands of a WWTP. 
Usually, the temperature in a digestion tower is around $35^{\circ} \mathrm{C}$, and administrative and operational buildings are even less tempered. High temperature heat can be provided by CHP generation from cooling water at around 80 to $90^{\circ} \mathrm{C}$ and exhaust gas with around several hundred ${ }^{\circ} \mathrm{C}$. Another negative aspect of this practice can be found in the fact that, today, excess heat often is lost or even has to be "destroyed" due to the lack of internal heat demand in WWTPs, especially during the summer season. In this context, the Swiss canton of Berne has released a new directive (Sutter et al. [20]) which prohibits the application of digester/biogas in CHP units, if the consumption of the entire electric and thermal energy produced cannot be guaranteed. In regard to electricity, meeting this requirement is usually not an issue. However, in regard to heat, it certainly is a big challenge, especially during the summer season. Alternatively, at least parts of the digester/biogas could be fed into the natural gas grid after treatment (Jacob et al. [21]) or excess heat might be discharged to a local district heating network (Picardo et al. [22]). Both options certainly can be valuable for decreasing the amount of (unused) excess heat. However, the aspect of energy efficiency in terms of temperature levels still remains unaffected.

This is the point at which we believe wastewater heat recovery could come into play. As presented above, the potential of the available, but still widely untapped, heat in the effluent of WWTPs is well documented in the literature. Furthermore, ambient heat sources, such as wastewater in combination with subsequent heat pump application, are most appropriate for low (to moderate) temperature supply (Zach et al. [23]), which matches well with the standard temperature demand ranges at a common WWTP. Shifting the WWTP internal heat supply from digester/biogas towards wastewater heat would generate a triple benefit. First, the activation of wastewater heat would release digester/biogas or its combustion heat for other purposes beyond the premises of a WWTP (e.g., heat and warm water supply in adjacent settlement structures). Second, the consideration of adequate temperature levels in heat supply supports a more efficient use of the available energy sources. Third, selling (thermal) energy to third parties (e.g., municipal energy supplier) could create an additional income for wastewater utilities.

In the course of an Austrian research project Gruber-Glatzl et al. [24] addressed the concept of integrating wastewater heat recovery and digester/biogas-based CHP generation to (partly) supply a local district heating network. In their work they present economic analyses of different heat pump scenarios (heat pump for WWTP internal supply only, for feed-in to the district heating supply and to the return flow, respectively). Almost concurrently, an implementation based on a similar concept is being realized at another location in Austria, of which this article is about. This article presents and summarizes the chosen approach and the key outcomes of the preceding feasibility study. The promising results of the project work shall provide information and motivation to stakeholders from the related fields (wastewater utilities, energy suppliers, spatial planners, municipalities, etc.). This is because WWTPs, as thermal power stations, can certainly provide a valuable contribution to a more local, renewable, and climate friendly energy supply of the future.

\section{Materials and Methods}

In this section the case study site and the chosen approaches, including the definition of the future energy supply scenario, and a feasibility study addressing the heat balance, the economic risks, climate protection benefits and social awareness, are introduced.

\subsection{Current Situation at the Case Study Site}

The investigated case study site is located in the Austrian province of Styria, in a medium-size town called Kapfenberg. The municipal WWTP has a treatment capacity of 49,000 population equivalents (PEs). The daily average wastewater flow is around $6700 \mathrm{~m}^{3} /$ day, and the annual average wastewater temperature is about $15^{\circ} \mathrm{C}$. For wastewater treatment, the plant applies mechanical (fine screen, sand trap, primary clarifier) and biological (activated sludge) processes. For sewage sludge treatment, the plant is equipped with a thickener, two digestion towers (total volume of $2400 \mathrm{~m}^{3}$ ) and a centrifuge for dewa- 
tering. Currently, the produced digester/biogas is being applied in a CHP unit $\left(124 \mathrm{~kW}_{\mathrm{el}}\right.$ and $165 \mathrm{~kW}_{\text {th }}$ ) to supply internal electricity and heat demands. Furthermore, two gas boilers are available for covering thermal peak demand. Excess digester/biogas can be buffered in a tank $\left(320 \mathrm{~m}^{3}\right)$ or, if necessary, can be flared. In addition, a ground-mounted photovoltaic installation $\left(100 \mathrm{~kW}_{\text {peak }}\right)$ contributes to the on-site electricity generation at the premises of the WWTP. The plant is further connected to the public electricity and natural gas grid. Today, especially during summer season, notable amounts of excess heat from the CHP unit remain unused, and the wastewater heat in the effluent of the WWTP is still untapped.

In close proximity to the WWTP (about $300 \mathrm{~m}$ of linear distance), at the opposite side of the receiving Mürz river, a new residential area named "Riverside" is under development. This complex comprises, in total, 220 apartments, 64 of which are refurbished and 156 are newly built. The site is located in an area which is designated as suitable for district heating supply, according to the concept of integrated spatial and energy planning (ISEP) that was adopted by the municipality as part of the local development strategy. The basic idea of ISEP is the joint development of energy-efficient settlement structures and sustainable energy supply [25]. The local energy supplier intends a climate-friendly heat supply for space heating and hot water provision. For this purpose, a wood chip incineration plant has been built at the premises of the WWTP (basically due to space availability) and a subsequent (local) district heating network was set-up to supply the residential development zone (current operating temperature is $70^{\circ} \mathrm{C}$, in case of further expansion of the network a rise to $90{ }^{\circ} \mathrm{C}$ due to still existing "conventional" heating systems is considered). To further increase and to diversify the share of renewable energy in the system, the public energy supplier showed interest in also considering high temperature CHP heat from digester/biogas combustion of the WWTP. In this case, however, the WWTP internal heat supply would require the activation of a new thermal heat source to further meet their own demand of low temperature heat, mainly required for the heating of the digestion towers. The following Figure 1 gives an overview on the localization of the WWTP and the "Riverside" residential area.

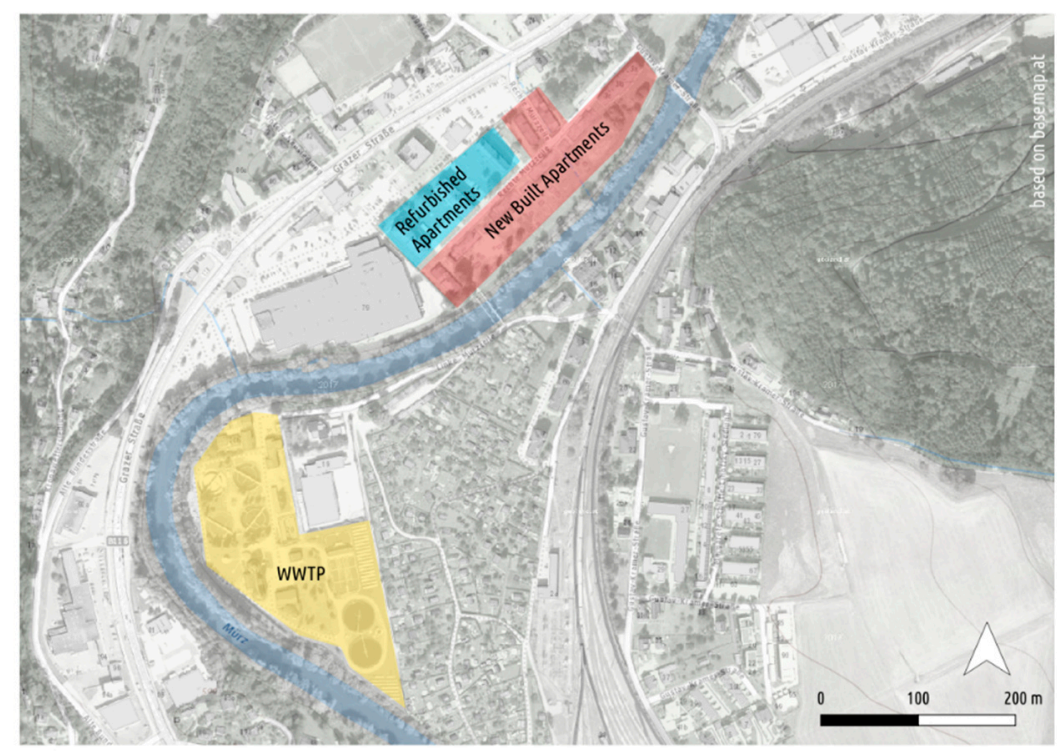

Figure 1. Site plan of the WWTP and the "Riverside" residential area highlighting refurbished and future new built appartments (Hrdy [26] and basemap.at, adapted).

\subsection{Defintion of Future Supply Scenario}

To make the high temperature heat from digester/biogas combustion available for supplying the high temperature heat demand of the residential area, an alternative source for the WWTP internal heat demand has to be activated. This demand primarily con- 
cerns low temperature requirements, like heating of the digestion towers, office buildings and workshops. Therefore, the application of wastewater heat recovery is, evidently, an opportunity.

However, due to hygienic (legionella protection in water supply) and economic reasons (the radiator-based heating system of the building units would have to be changed), not all buildings of the WWTP should be supplied by low temperature heat. Consequently, the existing buildings were subdivided into those dependent on high temperature heat supply (primarily administrative and residential buildings) and those suitable for low temperature heat supply (digesters, garages, workshops and other operational buildings).

To facilitate the intended external heat supply, the existing infrastructure has to be modified as follows: (1) WWTP internal (low temperature) heat supply system: a heat exchanger (HE) has to be installed in the effluent of the WWTP and subsequently connected to an externally positioned heat pump. Furthermore, the heat pump (HP) itself has to be integrated into the supply grid that is providing thermal energy to the digestion towers as well as the operational buildings ("frost-free buildings"). This might also require a certain adaption/expansion of the existing heating network of the WWTP; (2) digesters/sewage sludge heating: the heat exchangers of the digestion towers have to be replaced with equipment compatible with the new temperature level in the supply system; (3) external (high temperature) heat supply line: the WWTP, particularly its CHP unit, has to be connected to the local district heating system ("Riverside" network). This supply line shall still include the administrative buildings with a small residential section ("heated buildings"), primarily to further provide appropriate temperature levels for hot water production. The visualization of the future supply scenario is displayed in the following Figure 2.

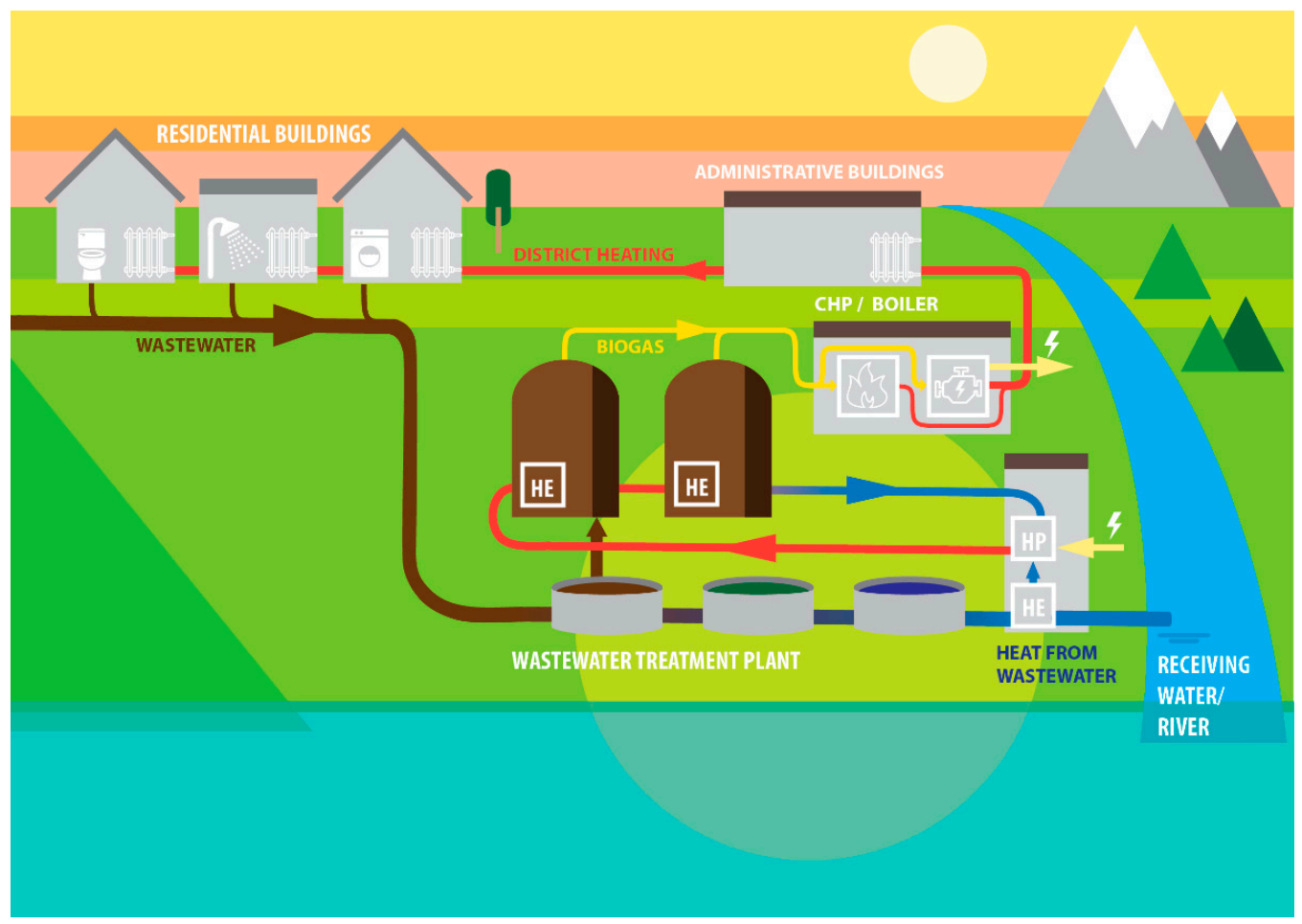

Figure 2. Visualization of the intended future supply scenario (Hrdy [26], adapted).

According to Kretschmer et al. [27] the use of energy from wastewater beyond the premises of a WWTP is a rather interdisciplinary issue concerning different thematic fields and stakeholders. To take this fact into account, the project consortium, right from the beginning, involved a broad-based group of specialists, including the local wastewater utility, the local energy supplier, the municipality, as well as research groups from various 
disciplines, such as sanitary engineering, integrated energy and spatial planning, and heat supply engineering.

The supply scenario presented above was followed by a collaborative discussion addressing the different perceptions, reservations, and strategic considerations of the involved stakeholders, as well as the local boundary conditions (e.g., future municipal development, pilot character of the intended solution). Finally, the joint supply scenario development resulted in a solution receiving broad consensus, acceptance and support of the local stakeholders. The elaboration of an intended supply (implementation) scenario constituted the preliminary step of the feasibility study analysis, which now will be further explained in the following section.

\subsection{Feasibility Study Procedure}

To provide a sound basis for deciding on the practical implementation of the defined supply scenario, the subsequent feasibility study tackled the following four aspects: (1) heat balance, (2) economic risk, (3) climatic benefit, and (4) social awareness.

\subsubsection{Heat Balance}

The heat balance addresses two aspects: first, the WWTP internal and external heat demand and, second, the wastewater-based energy generation from digester/biogas application in the CHP unit and from wastewater heat recovery in the effluent of the WWTP.

The heat demand of the WWTP operational and office buildings was (widely) available due to two continuous heat consumption measurements permanently installed at the WWTP. For those buildings not equipped with proper measurement, the heat demand was estimated based on inventory plans of the buildings and the existing heating system according to OIB [28].

The heat demand of the two digestion towers has not been recorded directly to date, but could be derived from the measured consumption of natural and digester/biogas (under consideration of the thermal efficiency of the CHP unit). However, in the case of the presented project, the heat demand was estimated from calculating the required energy for heating the available amounts of primary and secondary sludge (about $100 \mathrm{~m}^{3} /$ day, heated from measured wastewater temperature level to the targeted digestion temperature level of $40.5^{\circ} \mathrm{C}$ ), and also considering distribution and transmission heat loss (considering, amongst others, the outside air temperature and the surface of the digester). This calculation approach is, anyway, well known and documented in the literature (e.g., Lindtner [29]).

The external heat demand of the "Riverside" residential area has been estimated in a preceding work supported by the local energy supplier (Sommerauer and Wieland [30]). In addition, the measured heat consumption data from those buildings that are already completed and occupied (Wieland [31]) was used to verify and "calibrate" the estimated values.

In regard to the heat supply potential the basic situation is as follows. The available (maximum) thermal energy from digester/biogas is based on the thermal potential of the CHP unit (165 kW), implying a full capacity of $3960 \mathrm{kWh} /$ day. The available (maximum) energy from wastewater heat recovery considering a $200 \mathrm{~kW}$ heat pump results in $4800 \mathrm{kWh} /$ day. The heat pump size was derived during supply scenario development according to the approach presented by Gruber-Glatzl et al. [24]. Hereby, the size selection basically orientates on the maximum WWTP internal heat demand. The first step of the heat supply calculation concerns the wastewater heat pump and the low temperature heat demand (compare Equation (1)).

$$
\mathrm{dQ}_{\mathrm{LT}}[\mathrm{kWh}]=\mathrm{Q}_{\text {WWTP_LT }}[\mathrm{kWh}]-\mathrm{Q}_{\max \_ \text {HP }}[\mathrm{kWh}]
$$

If the maximum heat generation of the heat pump $\left(\mathrm{Q}_{\max \_\mathrm{HP}}\right)$ is higher than the WWTP internal low temperature heat demand ( $Q_{\text {WWTP_LT }}$ ), the demand can be fully covered by the heat pump. In this case, the actual heat supply of the heat pump is equal to the WWTP internal low temperature heat demand. 
If the WWTP internal low temperature heat demand is higher than the maximum heat generation of the heat pump, the actual heat supply is equal to the maximum (possible) supply of the heat pump. In this case, the still uncovered WWTP internal low temperature heat demand has to be covered by CHP heat (also see Equation (2)).

The second step of the heat supply calculation basically concerns the CHP unit and the WWTP internal (QWWTP_HT) and external (QEXT_HT) high temperature demand (compare Equation (2)). However, as already indicated, in the case of insufficient heat pump supply (the maximum heat generation of the heat pump is lower than the WWTP internal low temperature heat demand), the calculation of the CHP heat supply also considers the covering of this gap in low temperature heat supply ( $\mathrm{dQ}_{\mathrm{LT}}$ ) (compare Equation (3)).

If the total high temperature heat demand is higher than the maximum heat generation of the CHP unit, the actual heat supply is equal to the maximum (possible) supply of the CHP unit. Hereby, the uncovered heat demand must be supplied by the backup system of the energy utility (woodchip incineration).

If the total high temperature heat demand is lower than the maximum (possible) heat supply of the CHP unit, the surplus heat will be used to (partly) supply low temperature demand. This might not be the most efficient heat application, but it helps in avoiding $\mathrm{CHP}$ heat being unused and reduces the workload of the heat pump.

$$
\begin{gathered}
\mathrm{dQ}_{\mathrm{HT}}[\mathrm{kWh}]=\mathrm{Q}_{\text {max }_{-} \mathrm{CHP}}[\mathrm{kWh}]-\mathrm{Q}_{W W T P_{-} \mathrm{HT}}[\mathrm{kWh}]-\mathrm{Q}_{\text {EXT_HT }}[\mathrm{kWh}] \\
\text { if } \mathrm{dQ}_{\mathrm{LT}}<0 \\
\text { or }
\end{gathered}
$$

$$
\begin{gathered}
\mathrm{dQ}_{\mathrm{HT}}[\mathrm{kWh}]=\mathrm{Q}_{\text {max_CHP }}[\mathrm{kWh}]-\mathrm{Q}_{\mathrm{WTTP} \_\mathrm{HT}}[\mathrm{kWh}]-\mathrm{Q}_{\mathrm{EXT} \_\mathrm{HT}}[\mathrm{kWh}]-\mathrm{dQ}_{\mathrm{LT}} \\
{[\mathrm{kWh}]} \\
\text { if } \mathrm{dQ}_{\mathrm{LT}} \geq 0
\end{gathered}
$$

To estimate the electricity demand of the wastewater heat pump, the coefficient of performance as a ratio between electricity input and related heat output is of great relevance (compare Equation (4)). In the presented work, the dimensionless COP was estimated by applying the operation temperature of the heating system $\mathrm{T}_{\mathrm{op}}\left[{ }^{\circ} \mathrm{K}\right]$ (in our case $55{ }^{\circ} \mathrm{C}$ ), the gradient for evaporator or condenser heat exchanger $\mathrm{dT}\left[{ }^{\circ} \mathrm{K}\right](3 \mathrm{~K})$, the wastewater temperature $\mathrm{T}_{\mathrm{WW}}\left[{ }^{\circ} \mathrm{K}\right.$ ] (varying from 11.4 to $21.7^{\circ} \mathrm{C}$ ), and a dimensionless quality grade $\mathrm{n}(0.55)$ for compensating the mismatch between the ideal and real Carnot process (compare Equation (5)).

$$
\begin{gathered}
\mathrm{Q}_{\mathrm{el}, \mathrm{HP}}=\mathrm{Q}_{\mathrm{th}, \mathrm{HP}} / \mathrm{COP} \\
\mathrm{COP}=\left(\mathrm{T}_{\mathrm{op}}+\mathrm{dT}\right) /\left(\mathrm{T}_{\mathrm{op}}+2 * \mathrm{dT}-\mathrm{T}_{\mathrm{WW}}\right) * \mathrm{n}
\end{gathered}
$$

\subsubsection{Economic Risk}

The cost estimation (estimation of economic risk) of the intended implementation is based on a "static" comparison of revenues (including savings) and costs (for investment and operation and maintenance) and is achieved by applying a pre-defined (expected) payback period and a pre-defined (intended) heat price for the wastewater heat sold to the district heating network (compare Equation (6)). The appropriate values can then be derived by iterative calculations. It is assumed that the revenues must, at least, compensate the costs.

$$
\begin{gathered}
(\text { revenue }[\text { EUR } / \mathrm{a}]+\text { savings }[\text { EUR } / \mathrm{a}]) * \text { period }[\mathrm{a}]- \\
\text { investment }[\mathrm{EUR}]-\text { operation \& maintenance }[\mathrm{EUR} / \mathrm{a}] * \text { period }[\mathrm{a}] \geq 0
\end{gathered}
$$

Finally, related economic statements are reduced to payback times at a defined heat price. Although not as sophisticated as "common" cost accounting, this approach was chosen by the project consortium as it is considered to provide a quick and appropriate (first) impression on the economic risk. In addition, it is relatively easy to handle, as it incorporates rather low input data requirements and neglects hard-to-predict long-term 
cost effects (development of (fossil) energy costs, future $\mathrm{CO}_{2}$ taxes, etc.). By changing the numbers, the formulae can be used for sensitivity analyses to identify tipping points of economic feasibility of changing boundary conditions.

The achievable revenue concerns the amount of excess heat sold to the district heating network, as well as potential savings of natural gas at the WWTP due its coverage by wastewater heat. Funding opportunities have not been considered here. The investment cost of the required installations (including the connection line from WWTP to district heating network, wastewater heat exchanger, wastewater heat pump, related connection lines and adaption of the existing heat supply system, and sewage sludge heat exchanger) were collected by calling for related tenders. The costs for operation and maintenance of the new installations were defined as a proportion of the related investment costs (according to Austrian standard ÖNORM M 7140 [32], applying 4\% per year for the heat pump and $1 \%$ per year for all other installations. Operation and maintenance costs also consider the additional electricity demand that is required to run the wastewater heat pump.

In the context of cost calculation, it also has to be mentioned that the local stakeholders have decided, in any case, to only realize the intended implementation in two phases. In the first, the WWTP shall be connected to the district heating network to enable a feed-in of (seasonal) excess heat from the CHP unit. Here, the WWTP internal heat supply still remains untouched. Only in the second phase will the WWTP internal heat supply be modified towards low temperature heat supply from the effluent, which will also further increase the share of CHP heat available to supply WWTP external demand.

Consequently, the cost estimations of phase 1 are rather simple. In regard to Equation (6), the revenue from the sale of excess heat needs only to be compared to the investment, operation and maintenance costs of the pipeline connecting the WWTP to the district heating network. The heat price and the considered period (payback time) will be defined in the price ranges of local heat supply forms and will be changed iteratively until the derivation of appropriate values is achieved.

Compared to phase 1 , the cost estimation for phase 2 is more complex, as it does not only address external excess heat supply but also continuous WWTP internal heat supply (e.g., digestion towers, operational buildings). Having Equation (6) in mind again, the revenue now considers not only the revenue from heat sale but also the possible internal savings of the WWTP in terms of natural gas (due to substitution by wastewater heat). The costs for investment, operation and maintenance include all technical installations (heat pump, heat exchangers, etc.) as well as the additional electricity costs of the heat pump. As for phase 1 , the heat price and the considered period have to be iteratively adapted again.

\subsubsection{Climate Protection Benefit}

Apart from an efficient use of renewable energies, the reduction of $\mathrm{CO}_{2}$ emissions is an important issue in the fight against climate change. Consequently, the investigations of the presented feasibility study also address climate protection benefits related to the intended solution.

Today, heat supply in the concerned area is still widely dominated by natural gas. Consequently, the exclusive supply of the designated (internal and external) heat demand by natural gas serves as reference state. This will be compared to (equivalent) $\mathrm{CO}_{2}$ emissions from alternative wastewater heat pump usage, applying different electricity mixes (compare Equation (7)). Table 1 displays the considered $\mathrm{CO}_{2}$ emission factors for different energy sources, according to UBA [33].

$$
\begin{gathered}
\mathrm{CO}_{2} \text { equ. emissions }[\mathrm{kg}]=\text { energy demand }[\mathrm{kWh}]^{*} \\
\text { emission factor }\left[\mathrm{kg} \mathrm{CO} \mathrm{CO}_{2} \text { equ. } / \mathrm{kWh}\right]
\end{gathered}
$$


Table 1. $\mathrm{CO}_{2}$ emission factors for different energy carriers incl. upstream chain (UBA [33], adapted).

\begin{tabular}{|c|c|}
\hline Energy Source & $\begin{array}{l}\mathrm{CO}_{2} \text { Emission Factor } \\
{\left[\mathrm{kg} \mathrm{CO} \mathrm{CO}_{2} \text { equ./kWh] }\right.}\end{array}$ \\
\hline Natural gas (status quo) & 0.271 \\
\hline Electricity mix Austria & 0.258 \\
\hline Power Plant Park Austria & 0.196 \\
\hline Eco-Label “Green Electricity" & 0.016 \\
\hline
\end{tabular}

Hereby, "Power Plant Park Austria" only considers domestic electricity generation, while "Electricity Mix Austria" also includes the import of electricity. "Green Electricity" only comprises electricity generated from renewable sources.

Deliberately, the approach to determine the climatic benefit of the intended supply scenario is kept very simple and general. It aims only at roughly displaying the $\mathrm{CO}_{2}$ reduction potential of the investigated solution. More profound information on this issue is, anyway, well documented in the literature (Neugebauer et al. [10], Kollmann et al. [34]).

\subsubsection{Social Awareness}

According to Kretschmer et al. [27], the attempt to establish wastewater as a source of renewable energy requires the early involvement of relevant stakeholders. In this context, the interdisciplinary set-up of the project consortium should guarantee the development of a jointly accepted solution. Furthermore, it should also support the involved stakeholders to gain knowledge by providing direct insight into the circumstances of other professional fields.

To expand the stakeholder related activities, it was decided by the project consortium to also include the local population (inhabitants of the "Riverside" area) in awarenessraising activities. For providing information on the topic of energy supply from wastewater in general and on the intended practical implementation in particular, several articles in local and regional newspapers were published. Furthermore, to actively include the public, an open workshop was held on-site. During this event a pre-formulated questionnaire (20 questions, with only yes/no answering possibility to facilitate a quantitative analysis) was distributed among the participants in order to also collect information on the perceptions, opinions and attitudes of the future heat consumers.

\section{Results}

\subsection{Heat Balance}

The presented results of the heat balance concern the following aspects: internal demand for office/operational buildings and the digesters, external demand of the residential area "Riverside", and the heat generation from CHP application of digester/biogas and wastewater heat recovery in the effluent of the WWTP. The energy/heat demand figures have not been collected/calculated by the authors of this article but were provided from other project partners. Internal demands are documented in the project report (Zöscher et al. [35]), and external demands are described in the already mentioned preceding work supported by the local energy supplier (Sommerauer and Wieland [30]). For better readability, we decided to present these data here, although they should largely be understood as material used in this article.

\subsubsection{Heat Demand of the WWTP and "Riverside"}

The following Table 2 displays the WWTP internal heat demands. Depending on the temperature level required, it distinguishes between "heated" and "frost-free" buildings. The former comprises the administrative building which will be further supplied with high temperature (HT) heat from digester/biogas combustion. The latter concerns operational buildings which will be connected to the low-temperature (LT) heating systems supplied by the wastewater heat pump. The digesters, which will also be included in the lowtemperature network, are additionally illustrated. 
Table 2. WWTP internal heat demand for heated (administrative) and frost-free (operational) buildings as well as digestion towers (Zöscher et al. [35], adapted).

\begin{tabular}{|c|c|c|c|c|c|c|c|c|c|c|c|c|c|}
\hline $\begin{array}{l}\text { Heat Demand } \\
{\left[\mathrm{kWh}_{\mathrm{th}} / \mathrm{day}\right]}\end{array}$ & Jan & Feb & Mar & Apr & May & Jun & Jul & Aug & Sep & Oct & Nov & Dec & Mean \\
\hline $\begin{array}{l}\text { Building heated } \\
\text { (HT) }\end{array}$ & 1572 & 1352 & 1020 & 624 & 249 & 63 & 8 & 22 & 201 & 634 & 1124 & 1495 & 694 \\
\hline $\begin{array}{l}\text { Building } \\
\text { frost-free (LT) }\end{array}$ & 642 & 549 & 388 & 225 & 62 & 18 & 2 & 0 & 51 & 137 & 394 & 590 & 253 \\
\hline Digesters (LT) & 4084 & 4188 & 4144 & 3845 & 3506 & 3236 & 3124 & 2921 & 3036 & 3264 & 3558 & 3989 & 3571 \\
\hline
\end{tabular}

It is clear to see that the heat demand of all consumers is highest during the colder season (October to April). During the warmer season in the buildings, almost no heat consumption occurs apart from hot water production. The digesters have continuous heat demand, but summer values are also decreased due to hot outside air temperatures leading to higher wastewater/sludge temperatures and less transmission loss.

Table 3 provides an overview on the (estimated) heating demand of the fully developed residential area "Riverside". Here again, the highest heat demand is expected during the colder season, while in summer heat demand is reduced to the requirements of hot water production.

Table 3. External heat demand of "Riverside" residential area (Sommerauer and Wieland [30], adapted).

\begin{tabular}{|c|c|c|c|c|c|c|c|c|c|c|c|c|c|}
\hline $\begin{array}{l}\text { Heat Demand } \\
\text { [kWh/day] }\end{array}$ & Jan & Feb & Mar & Apr & May & Jun & Jul & Aug & Sep & Oct & Nov & Dec & Mean \\
\hline "Riverside" & 4511 & 5258 & 4179 & 1070 & 563 & 478 & 478 & 478 & 810 & 1887 & 3571 & 4825 & 2326 \\
\hline
\end{tabular}

\subsubsection{Heat Generation and Supply}

Heat supply from the wastewater heat pump (HP) and digester/biogas application in the CHP unit are presented in Table 4. The considered heat pump can provide thermal energy of up to $4800 \mathrm{kWh}$, and the CHP unit can provide energy of up to $3960 \mathrm{kWh}$.

Table 4. Heat pump and CHP based heat supply (Hrdy [26], adapted).

\begin{tabular}{|c|c|c|c|c|c|c|c|c|c|c|c|c|c|}
\hline $\begin{array}{l}\text { Heat Supply } \\
\text { [kWh/day] }\end{array}$ & Jan & Feb & Mar & Apr & May & Jun & Jul & Aug & Sep & Oct & Nov & Dec & Mean \\
\hline $\mathrm{HP}(\mathrm{LT})$ & 4726 & 4737 & 4531 & 1804 & 394 & 0 & 0 & 0 & 139 & 1962 & 3952 & 4579 & 2223 \\
\hline $\mathrm{CHP}(\mathrm{HT})$ & 3960 & 3960 & 3960 & 3960 & 3960 & 3795 & 3613 & 3421 & 3960 & 3960 & 3960 & 3960 & 3871 \\
\hline
\end{tabular}

It is important to note that the wastewater heat pump will only be operated if the CHP unit is not able to fully supply both the external heat demand of the "Riverside" residential area as well as the entire WWTP internal demand. This is to make the best use of the available digester/biogas. In our specific case, the CHP unit can supply all of the demand in the summer months from June to August. Hence, the heat pump is switched off during this time. In contrast, during the winter months, from November to March, the heat pump is almost permanently under operation. April/May and September/October are transition periods during which both the CHP unit and heat pump are partly required to cover the total heat demand.

Figure 3 visualizes the comparison of heat demand and supply. The displayed columns summarize the different heat demands (digesters, frost-free and heated buildings at the WWTP and the new build and refurbished housings at "Riverside" residential area). The dotted lines represent the heat supply, either from the wastewater heat pump only or the combined supply of both the heat pump and the CHP unit. It can be seen that the heat pump will cover the internal low temperature heat demand during the winter season (November to March). Consequently, the amount of CHP excess heat to be supplied to the district heating network can be maximized. However, even so, the total heat demand of 
"Riverside" cannot be met during these months. Consequently, this gap has to be supplied by the back-up system of the municipal energy supplier: a wood chip incineration plant.

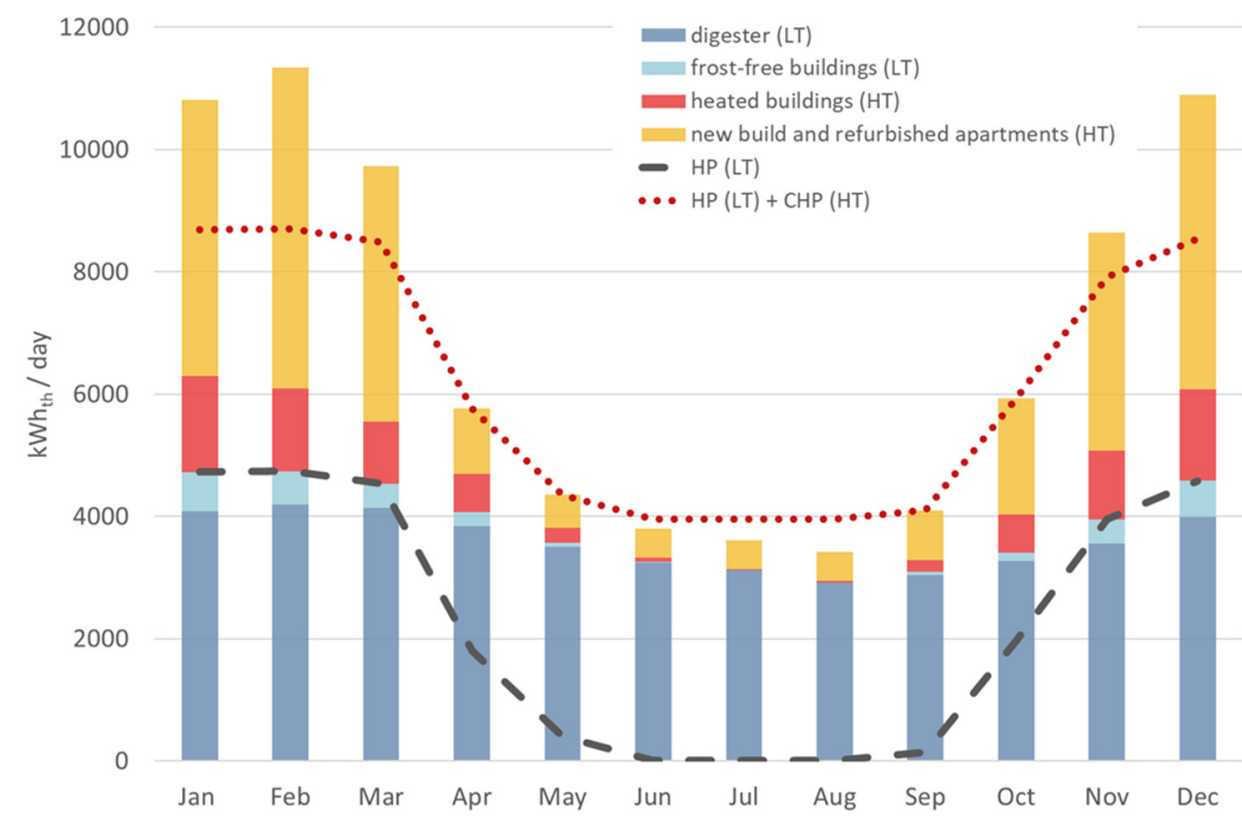

Figure 3. Comparison of heat demand and supply from the investigated case study (Hrdy [26], adapted).

Finally, the following Table 5 shows the heat coverage rate of the wastewater- based heat supply (heat pump and CHP unit) in regard to the total internal and external demand. Even in the cold season, up to $80 \%$ of the entire demand can be supplied with the intended infrastructure. The rest has to be provided by the backup system. Hereby, the related heat supply amounts to an average value of $750 \mathrm{kWh} /$ day for the year. During the warm season, the energy from the WWTP can cover all demand.

Table 5. Heat coverage of WWTP supply in relation to the total heat demand (Hrdy [26], adapted).

\begin{tabular}{|c|c|c|c|c|c|c|c|c|c|c|c|c|c|}
\hline $\begin{array}{l}\text { Heat Coverage } \\
{[\%]}\end{array}$ & Jan & Feb & Mar & Apr & May & Jun & Jul & Aug & Sep & Oct & Nov & Dec & Mean \\
\hline WWTP & 80 & 77 & 87 & 100 & 100 & 100 & 100 & 100 & 100 & 100 & 91 & 78 & 93 \\
\hline Back-up system & 20 & 23 & 13 & 0 & 0 & 0 & 0 & 0 & 0 & 0 & 9 & 22 & 7 \\
\hline
\end{tabular}

\subsubsection{Electricity Demand of the Heat Pump}

Finally, an important aspect for subsequent investigations (focusing on the economic and climatic aspects) is the electricity that is needed to run the heat pump. The related figures are presented in Table 6 below. Basically, the electricity demand of the heat pump is covered by grid supply, but it might also be (partly) covered by the CHP unit and the PV system that is installed at the premises of the WWTP. While the electricity generated from the latter can be considered renewable, the composition of the electricity mix applied in the public the grid is important in regard to estimating the $\mathrm{CO}_{2}$ emissions of the applied heat supply system (see Section 3.3). 
Table 6. Heat pump thermal supply and related electricity demand depending on the coefficient of performance (COP) (Hrdy [26], adapted).

\begin{tabular}{|c|c|c|c|c|c|c|c|c|c|c|c|c|c|}
\hline $\begin{array}{l}\text { Supply/ } \\
\text { Demand } \\
{[k W h / d a y]}\end{array}$ & Jan & Feb & Mar & Apr & May & Jun & Jul & Aug & Sep & Oct & Nov & Dec & Mean \\
\hline Heat supply & 4726 & 4737 & 4531 & 1804 & 394 & 0 & 0 & 0 & 139 & 1962 & 3952 & 4579 & 2223 \\
\hline $\mathrm{COP}$ & 3.73 & 3.67 & 3.70 & 3.93 & 4.17 & 4.38 & 4.48 & 4.63 & 4.48 & 4.24 & 4.05 & 3.76 & n. a. \\
\hline Electr. Demand & 1266 & 1290 & 1224 & 458 & 94 & 0 & 0 & 0 & 31 & 463 & 976 & 1217 & 582 \\
\hline
\end{tabular}

\subsection{Economic Risk}

The result of the heat balance analysis provides the basis to estimate the economic risk of the intended implementation. The project consortium decided for a two-step realization. Consequently, economic analyses are made for the two phases. Phase 1 solely concerns the connection of the WWTP and the district heating network to supply CHP excess heat (in summer). The period in question is the non-heating season from May to September. Phase 2 includes all other aspects, and is mainly concerned with the development of the wastewater heat-based supply system. The temporal focus here lays on the heating season from October to April.

\subsubsection{Implementation Phase 1}

The investment costs for connecting the WWTP to the district heating network is around 46,000 EUR (construction and connection of the pipeline, adaption of the WWTPs control system, etc.). The annual costs for operation and maintenance are estimated at $460 \mathrm{EUR} / \mathrm{a}$ ( $1 \%$ of the investment costs). The amount of excess heat for sale is around $85,000 \mathrm{kWh}$ for the period of concern (May to September). This value might appear rather low in regard to the supply potential of the CHP unit. However, evidently, the amount to be sold is determined by the actual heat demand of the "Riverside" residential area.

Based on these figures and with consideration of the iteratively determined heat price and consideration period (payback time), appropriate values can be defined. We have to leave this iterative work to the reader, as we have no permission from the project consortium to publish any intended heat prices. However, absolute numbers are of limited interest in an international context as they are strongly influenced by local spatial boundary conditions, taxes, subsidy regimes and overall cost structures and local competing energy supply options. Early experiences and real heat consumption measurements from the already occupied "Riverside" buildings indicate that the applied summer heat demand was underestimated to a significant extent. This additional demand could still be supplied with excess heat from the CHP unit. Based on these new findings, we now expect a reasonable annual revenue from the sale of heat after the entire residential area has been developed and occupied. This would reduce the possible payback time of phase 1 considerably.

\subsubsection{Implementation Phase 2}

Phase 2 is more complex, as it does not only concern costs for investments, operation and maintenance and revenues from the sale of heat, but also includes electricity costs for running the heat pump and possible WWTP internal savings of natural gas (to occasionally cover winter peak demand) due to its substitution with wastewater heat.

The (net) investments (heat pump, wastewater and sewage sludge heat exchangers, additional piping, etc.) amount to a sum of about 143,000 EUR, and, in addition, the annual costs for operation and maintenance are estimated at around $3400 \mathrm{EUR} / \mathrm{a}(4 \%$ of the investment costs for the heat pump, 1\% applied to all other positions). The annual costs for electricity consumption of the heat pump (about 212,000 kWh/a) are estimated at $26,000 \mathrm{EUR} / \mathrm{a}$. The estimated amount of excess heat for sale is approximately $490,000 \mathrm{kWh}$ for the concerned period (October to April). The annual savings of natural gas (around $37,600 \mathrm{~m}^{3} / \mathrm{a}$ ) are expected in the range of $17,000 \mathrm{EUR} / \mathrm{a}$. 
Based on these figures and in the context of a specific heat price and consideration period, here again, appropriate values can be derived. At this stage, we also have to point out, again, that we cannot propose any heat price. However, the application of different heat prices revealed that the payback time is very sensitive, even to rather small changes. This might not be expected at first glance, but the reason for this can be found in the great influence of the heat pump's electricity consumption on the total costs. The savings in terms of natural gas slightly buffer this dynamic, but the clearly higher electricity price in comparison to the heat price is of crucial importance here. In this context, the expansion of WWTP internal electricity generation (photovoltaics, hydropower, and, where applicable, wind power) should certainly receive more attention in the future. However, at current electricity and natural gas prices, the economic analysis of phase 2 shows that in order to achieve an acceptable payback time, the applicable heat price should be slightly higher than the one derived for phase 1 . However, it remains in a range which is still acceptable for the local energy supplier and the other decision makers. As an additional benefit, the related heat price only depends on local and regional resources and is thus not subject to international market variations as is the case for fossil energies (e.g., the massive increase in oil and natural gas prices in Autumn 2021). This provides great contributions to an increase in economic resilience of the local heat supply.

\subsection{Climate Protection Benefit}

Considering the fact that the investigated area is primarily supplied by natural gas today, the implementation of the intended wastewater-based supply scenario entails a significant reduction in $\mathrm{CO}_{2}$ emissions (due to the substitution of natural gas).

For sole heat substitution, the emission factor of natural gas can be applied (implementation phase 1). In the current context, a total amount of 85,000 kWh from CHP excess heat is being supplied to the "Riverside" residential area (from May to September). Herby, $\mathrm{CO}_{2}$ emissions in the dimension of $23 \mathrm{t}$ can be saved (compared to an adequate supply by natural gas).

If heat pump operation is also being included (implementation in phase 2), the related electricity consumption has to be considered as well. The following Figure 4 displays $\mathrm{CO}_{2}$ emissions for conventional natural gas-based heating and wastewater heat pump application with varying electricity mixes. The calculations apply an annual heat supply of $811 \mathrm{MWh} / \mathrm{a}$ and an electricity demand of $212 \mathrm{MWh}_{\mathrm{el}} / \mathrm{a}$ for heat pump operation $\left(55^{\circ} \mathrm{C}\right)$.

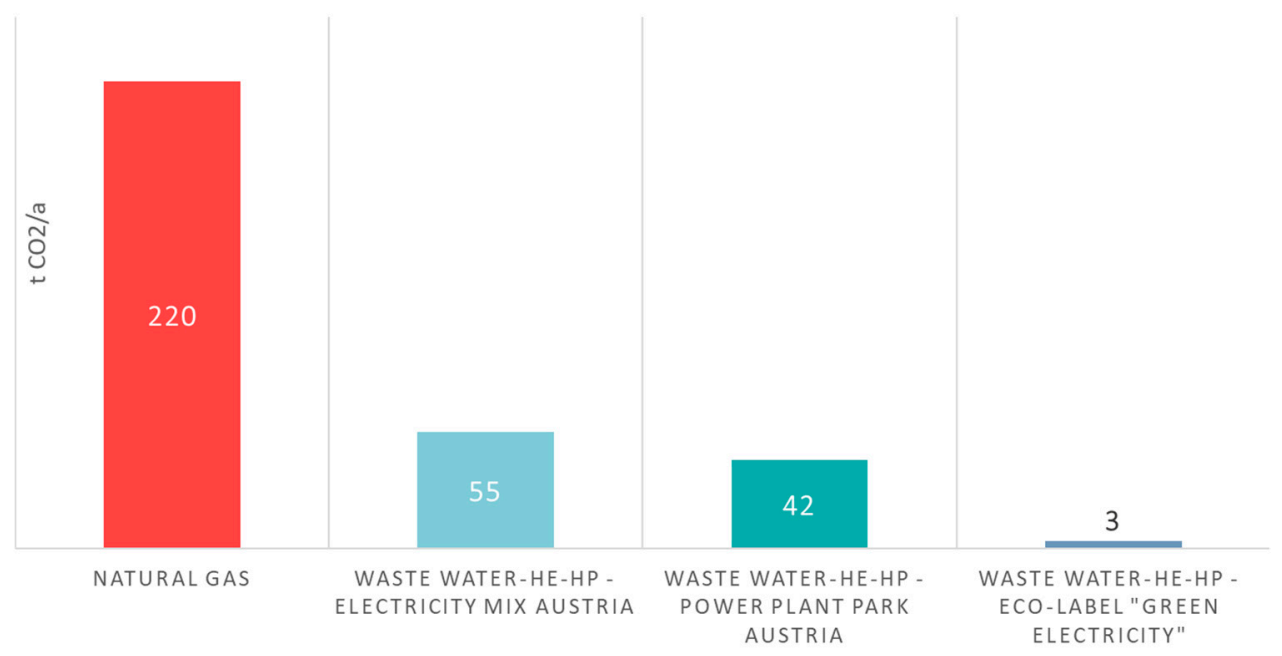

Figure 4. Comparison of the $\mathrm{CO}_{2}$ emissions depending on energy/electricity mix for implementation phase 2 (Hrdy [26], adapted). 
The comparison of $\mathrm{CO}_{2}$ emissions clearly demonstrates the climate protection benefit of the intended heat supply scenario. However, the impact of the applied electricity mix is also an important factor to be considered.

\subsection{Social Awareness}

Apart from intensifying the cooperation and exchange of the different professionals in a joint project consortium, the applied participatory approach also aimed at the future energy/heat consumers (the inhabitants of "Riverside"). In this context, an on-site workshop for the inhabitants of the concerned area was held. The aim of the event was twofold. On one hand, the public should be informed about the general possibility of wastewater as a source of renewable energy. On the other hand, the project consortium intended to collect information concerning the public awareness and perception in regard to the topic in general and to the intended supply scenario in specific.

Basically, the number of participants (12 persons) was comparatively small and not representative of the approximately 500 expected future residents of the "Riverside Project" once finalized. However, at the moment 20 percent of the flats are already built and occupied by about 100 residents. Therefore, we reached a bit more than 10 percent of the current population. Nonetheless, we assume that we only reached people with a high interest in the energy transition, as can be seen below. The age split showed a dominating group of participants from the generation 50+ (almost 85\%). The education split proved that the educational background was rather evenly distributed, with slight tendencies towards higher education. About half of the participants were locals, but most of the participants were not inhabitants of the already-occupied new apartments.

To summarize the key outcomes, the interrogation revealed a great interest in climate protection and renewable energy of all participants $(100 \%)$. It was also common understanding $(100 \%)$ that measures to counteract climate change must be set at all (administrative) levels: EU, national, and regional. The interest in local energy policy is also very high (92\%). The majority of people were already well aware of the general possibility of energy generation from wastewater (75\%). A vast majority of participants were very positive in regard to using the energy from wastewater, not only in general but also in their specific local context (92\%). Furthermore, participants were convinced that energy from wastewater is of great public interest (84\%).

Finally, the interrogation drew a very positive attitude of the public/energy consumers in regard to the topic and the project. However, one important issue was raised in the discussion, which was not covered by the survey: the uncertainty of how the heat supply from wastewater could affect the heat bills of the consumers. Certainly, a rise in the heat price would find only relatively few supporters.

\section{Discussion}

\subsection{Feasibilty of the Intended Supply Scenario}

The heat balance analysis reveals that the WWTP internal heat demand (digestion towers and operational buildings) can easily be met through wastewater heat recovery applying a $200 \mathrm{~kW}$ heat pump (calculated on winter conditions). Due to the modification of internal supply, per day an annual average of around $3200 \mathrm{kWh} /$ day of CHP high temperature excess heat could be made available for being introduced into the local high temperature district heating network. During the winter season, at least $50 \%$ of the external heat demand (space heating and hot water production) could be covered with the available excess heat. During the summer season the available excess heat from the WWTP would be more than adequate for covering the entire external demand. Investigations also show that the available heat potential in the effluent of the WWTP is still far from being fully used (heat extraction of $5 \mathrm{~K}$ in the effluent would imply a heat pump based supply of more than $25,000 \mathrm{kWh} /$ day). Consequently, additional external heat demand could be supplied. In this context, Neugebauer and Stöglehner [36] state that not only settlement structures (residential, commercial, industrial) but also agricultural, aquacultural and 
silvicultural sites (greenhouses, stables, drying of woodchip and herbs) show considerable (low-temperature) heat demand. A targeted settlement development in close proximity to WWTPs could help to make the best use of the available heat potentials.

A detailed economic analysis of the designated application scenarios is a rather difficult task, as many important parameters incorporate notable uncertainties (future development of energy prices, proper discounting of costs, etc.). However, based on the applied, simplified calculation approach, the financial risk of the intended implementations appears quite acceptable. Depending on the variation of the possible heat price, the payback time moves in a range of around 10 years (not considering any subsidies). From a strictly economic perspective this period might appear rather high. However, one has to keep in mind that municipal planning horizons certainly apply longer perspectives, as public utilities are less profit-orientated than private ones. In addition, continuous heat demand and supply, both key aspects of economic operation (investment security), can be considered to be guaranteed because heat consumers are concurrently wastewater producers. Consequently, it is very likely, that the investment and operational costs will more than pay off during the service life of the technical installations. Increasing the costs of fossil energy sources and the expected introduction of carbon pricing schemes (in the case of Austria, the first steps have been announced for the beginning of 2022) as well as new funding opportunities will certainly bring additional financial benefit. Furthermore, we propose that times of massive climate protection demands concepts (as the one presented here) that lead to considerable reductions of greenhouse gas emissions might have different economic guiding principles going beyond classical approaches. In this context we strongly encourage the contrasting of short payback time and high interest rates with affordability that includes long term benefits. This is in line with sustainability considerations according to the UN sustainable development goals. From our analysis we can state that the proposed concept is both economically affordable and competitive with other existing forms of heat supply.

In regard to the climate benefit, one can note that both energy sources applied in the intended implementation - digester/biogas and wastewater heat-are considered to be renewable. For the latter, however, the electricity mix used to run the heat pump has strong relevance as it contributes to the $\mathrm{CO}_{2}$ emissions of the entire system. The presented investigations, as well as the international literature (Neugebauer et al. [10], Kollmann et al. [34], clearly shows the $\mathrm{CO}_{2}$ reduction potential of green power driven heat pump systems. The Austrian government aims at achieving 100\% renewable electricity generation by 2030 (EAG [37]), and the EU aims to become climate neutral by 2050 (European Commission [38]). This is certainly a very positive outlook on the climate protection potential of a wastewater-based energy supply.

The interdisciplinary set-up of the project consortium provided an appropriate basis for developing a solution of broad acceptance and support. The discussion and exchange among specialists from various fields gave all participants a better insight and understanding of the different professional positions and perspectives. However, raising awareness and knowledge in regard to wastewater-based energy supply did not only concern the project partners but also addressed the local population of the residential area. The interrogation of participants in a public workshop revealed a very open attitude to renewable and climate-friendly energy supply in general and to the intended supply scenario specifically. However, although energy consumers are very positive in regard to new approaches in energy/heat supply, one crucial concern for them is the constancy of the energy price/tariff. The concerned stakeholders are, anyway, aware of this point, and the heat price is a key parameter in any economic analysis. Finally, the work with the public confirmed the statement of Kretschmer et al. [27]: that awareness-building needs to target groups with tailored information which also has to be provided through appropriate channels (e.g., the youth will not be best reached by municipal newspapers).

Finally, it can be stated that the local decision makers considered the presented outcomes of the feasibility study to be promising. Phase 1 (supply of excess heat) was realized 
in summer 2020. Phase 2 (activation of wastewater heat in the WWTP effluent) is already agreed and shall go into operation in Summer 2022.

\subsection{Strengths and Weaknesses of the Applied Approach}

One of the core tasks of the presented analysis is the preparation of the heat balance. This analysis provides the data basis for subsequent financial and climatic investigations. Consequently, uncertainties in the heat balance will be passed on and thus should be kept in mind when interpreting results. In this context, the following aspects have to be mentioned: (1) uncertainties in regard to internal heat demand: due to the lack of complete measurements, heat consumption has to be estimated for certain buildings based on certain assumptions (especially for the digesters); (2) uncertainties in regard to external heat demand: due to the fact that the residential area is not fully developed at the moment, heat demand also has to be estimated here. The measurement data available from the already occupied buildings can be used as reference values. However, one has to keep in mind that data from 2020 and 2021 might not be fully representative due to several COVID-19 lock-down phases forcing people to stay home all day; (3) uncertainties in regard to energy/heat generation: heat recovery from wastewater has not been installed yet. Consequently, the related heat provision can also only be estimated. The same is true, to a certain extent, for the heat provision of the $\mathrm{CHP}$ unit (assumptions regarding this are simplistic due to the varying occupancy rate, and fluctuation in digester/biogas quality and quantity, etc.).

Finally, the input data for the economic analysis bears uncertainties. In addition, the economic analysis itself also has uncertainties: (1) uncertainties in regard to costs and revenues: the applied approach used to estimate/describe the economic risk of the intended application has a static character which neglects cost discounting and the development of energy prices; (2) uncertainties in regard to future $\mathrm{CO}_{2}$ taxes and subsidies: these aspects can have a strong influence on the heat price and estimated payback time, respectively. However, they are difficult to predict and thus are not considered in the analysis.

The project consortium agreed that how representative and sophisticated the cost assessment would be is strongly influenced by the uncertainties presented. Consequently, we decided to apply a simplified cost estimation. This approach provides a quick impression of the economic risk of the planned scenario in regard to a specific heat price and/or payback period. This information was considered to be adequate for decision making. Furthermore, the modular approach of realization (first, external CHP excess heat supply, second, internal wastewater heat pump supply) helps to minimize implementation risks, concomitantly ensuring a future expansion of the novel heat supply system (e.g., further exploitation of the wastewater heat potential by an additional heat pump). Finally, it was the interdisciplinary character of the project development which gave strong confidence to the decision makers, despite various uncertainties.

\subsection{Potential for Replication}

The concept of wastewater-based heat supply presented in this article addresses two aspects. On the one hand, thermal energy from digester/biogas combustion and, on the other hand, heat extraction from the wastewater. The former only concerns WWTPs which are equipped with anaerobic digestion. However, according to Neugebauer et al. [10], this applies to more than 160 WWTPs in Austria alone. In a more international context, the REEF $2 W$ project [39] presents a figure of around 900 of these plants in the Central European region (primarily focusing on Austria, Croatia, Czech Republic, Germany (the southern and eastern regions), and Italy (the northern region)). We consider these numbers as already very promising. However, they are far exceeded by the amount of WWTPs which are appropriate candidates for wastewater heat recovery. In this context, Neugebauer et al. [10] address those Austrian WWTP of a treatment capacity of at least 2000 population equivalents, indicating a total number of about 630. In the Central European context, again, the REEF $2 \mathrm{~W}$ project [39] presents an amount of around 6900 WWTPs in this size category 
(including, in addition to the countries already mentioned before, Hungary, Poland, Slovakia, and Slovenia). Finally, there is high potential to replicate the presented concept at other WWTPs around Europe and beyond. Taking into account the spatial context, about three quarters of the considered Central European WWTPs within settlements or near to settlement structures appear to be suitable for supplying wastewater heat to the surrounding settlement structures and should be subject to further detailed investigations.

\section{Conclusions}

For decades, from an energetic perspective, WWTPs have been considered to be "islands", primarily focusing on a high degree of (electric) energy self-sufficiency. Significant amounts of available thermal (excess) energy remained unused. These days, however, one can observe a paradigm change from seeing WWTPs as end-of-pipe waste disposal facilities towards WWTPs being understood as beginning-of-pipe resource recovery facilities.

This article presents a novel concept of modifying the internal heat supply of WWTPs to support an efficient use of thermal energy and to make excess heat available for WWTP external supply. Thereby, two thermal energy sources are being considered: the excess heat from digester/biogas combustion and heat recovery from the wastewater in the effluent of a WWTP. From an energetic perspective, the presented approach appears to be more than promising. The heat potential available in the effluent of the WWTP does not only meet, but even exceeds, internal demand by far. The economic analysis reveals that this innovative approach can already be competitive today, even without considering future $\mathrm{CO}_{2}$ taxing schemes or funding possibilities. Climate-related investigations also confirm the benefits of the novel concept, although the electricity mix applied to run the wastewater heat pump is of crucial importance here.

The implementation of climate actions on local level concerns a multitude of stakeholders, which can be supported by a participatory approach. For the presented project, the early involvement of all relevant local stakeholders (as well as of regional/national research institutions) and the set-up of an interdisciplinary working team has proven to be very successful. The direct cooperation of various disciplines supports mutual learning, the raising of awareness and a better understanding of other positions and perspectives. Furthermore, the interdisciplinary cooperation supports the development of best accepted solutions.

To improve future planning, WWTPs should become more aware of their thermal potential and the opportunities for efficient internal and external use. As it already exists for electricity at many WWTPs, the implementation of a proper monitoring concept for heat consumption and generation would be very valuable. This latter point has to be tackled by the WWTP operators. The former point is supported by this article.

Author Contributions: Conceptualization, F.K.; methodology, F.K., B.H., G.N.; software, B.H.; validation, F.K., B.H., G.N., G.S.; formal analysis, F.K., B.H.; investigation, B.H.; data curation, B.H.; writing —original draft preparation, F.K., B.H.; writing—review and editing, G.S.; visualization, B.H.; supervision, G.S.; project administration, F.K.; funding acquisition, F.K., G.S. All authors have read and agreed to the published version of the manuscript.

Funding: This research was funded by the wastewater utility Mürzverband with support of the Government of the Austrian Federal Province of Styria (Department for Energy and Housing, GZ: ABT15-67975/2018-33).

Institutional Review Board Statement: Not applicable.

Informed Consent Statement: Not applicable.

Data Availability Statement: No additional data available.

Acknowledgments: The presented research work is based on a cooperation between the wastewater utility Mürzverband, the energy supplier Stadtwerke Kapfenberg, the municipality of Kapfenberg (Stadtbaudirektion), AEE INTEC, the Austrian Energy Agency, and the University of Natural Resources and Life Sciences, Vienna. This article summarizes key outcomes of the related project report (quoted as source [35]) and the master thesis of the second author, which was elaborated in the course 
of the project (quoted as source [26]). In September 2021, the presented project was awarded with the Austrian "Kommunal Impuls Award", which recognizes municipal pacesetters of sustainable development. Furthermore, it was nominated for the Austrian Public Sector Award 2021, the Energy Globe Styria Award 2021, and the ÖGUT environmental prize 2020.

Conflicts of Interest: The authors declare no conflict of interest.

\section{References}

1. European Commission. Energy and the Green Deal-A Clean Energy Transition. Available online: https://ec.europa.eu/info/ strategy / priorities-2019-2024/european-green-deal/energy-and-green-deal_en (accessed on 9 September 2021).

2. Gandiglio, M.; Lanzini, A.; Soto, A.; Leone, P.; Santarelli, M. Enhancing the Energy Efficiency of Wastewater Treatment Plants through Co-digestion and Fuel Cell Systems. Front. Environ. Sci. 2017, 5, 70. [CrossRef]

3. Kretschmer, F.; Neugebauer, G.; Kollmann, R.; Eder, M.; Zach, F.; Zottl, A.; Narodoslawsky, M.; Stoeglehner, G.; Ertl, T. Resource recovery from wastewater in Austria: Wastewater treatment plants as regional energy cells. J. Water Reuse Desalin. 2016, 6, 421-429. [CrossRef]

4. $\quad$ Elías-Maxil, J.; van der Hoek, J.P.; Hofman, J.; Rietveld, L. Energy in the urban water cycle: Actions to reduce the total expenditure of fossil fuels with emphasis on heat reclamation from urban water. Renew. Sustain. Energy Rev. 2014, 30, 808-820. [CrossRef]

5. Kehrein, P.; van Loosdrecht, M.; Osseweijer, P.; Posada, J.; Dewulf, J. The SPPD-WRF Framework: A Novel and Holistic Methodology for Strategical Planning and Process Design of Water Resource Factories. Sustainability 2020, 12, 4168. [CrossRef]

6. Kehrein, P.; van Loosdrecht, M.; Osseweijer, P.; Garfí, M.; Dewulf, J.; Posada, J. A critical review of resource recovery from municipal wastewater treatment plants-Market supply potentials, technologies and bottlenecks. Environ. Sci. Water Res. Technol. 2020, 6, 877-910. [CrossRef]

7. Puyol, D.; Batstone, D.J.; Hülsen, T.; Astals, S.; Peces, M.; Krömer, J.O. Resource Recovery from Wastewater by Biological Technologies: Opportunities, Challenges, and Prospects. Front. Microbiol. 2017, 7, 2106. [CrossRef] [PubMed]

8. Schäfer, M.; Gretzschel, O.; Steinmetz, H. The Possible Roles of Wastewater Treatment Plants in Sector Coupling. Energies 2020, 13, 2088. [CrossRef]

9. Lichtenwoehrer, P.; Abart-Heriszt, L.; Kretschmer, F.; Suppan, F.; Stoeglehner, G.; Neugebauer, G. Evaluating Spatial Interdependencies of Sector Coupling Using Spatiotemporal Modelling. Energies 2021, 14, 1256. [CrossRef]

10. Neugebauer, G.; Kretschmer, F.; Kollmann, R.; Narodoslawsky, M.; Ertl, T.; Stoeglehner, G. Mapping Thermal Energy Resource Potentials from Wastewater Treatment Plants. Sustainability 2015, 7, 12988-13010. [CrossRef]

11. Spriet, J.; McNabola, A.; Neugebauer, G.; Stoeglehner, G.; Ertl, T.; Kretschmer, F. Spatial and temporal considerations in the performance of wastewater heat recovery systems. J. Clean. Prod. 2020, 247, 119583. [CrossRef]

12. Frijns, J.; Hofman, J.; Nederlof, M. The potential of (waste)water as energy carrier. Energy Convers. Manag. 2013, 65, 357-363. [CrossRef]

13. Hao, X.; Li, J.; van Loosdrecht, M.C.; Jiang, H.; Liu, R. Energy recovery from wastewater: Heat over organics. Water Res. 2019, 161, 74-77. [CrossRef] [PubMed]

14. Nielsen, S.; Hansen, K.; Lund, R.; Moreno, D. Unconventional Excess Heat Sources for District Heating in a National Energy System Context. Energies 2020, 13, 5068. [CrossRef]

15. Nagpal, H.; Spriet, J.; Murali, M.; McNabola, A. Heat Recovery from Wastewater-A Review of Available Resource. Water 2021, 13, 1274. [CrossRef]

16. Yang, X.; Wei, J.; Ye, G.; Zhao, Y.; Li, Z.; Qiu, G.; Li, F.; Wei, C. The correlations among wastewater internal energy, energy consumption and energy recovery/production potentials in wastewater treatment plant: An assessment of the energy balance. Sci. Total Environ. 2020, 714, 136655. [CrossRef] [PubMed]

17. Nakkasunchi, S.; Hewitt, N.J.; Zoppi, C.; Brandoni, C. A review of energy optimization modelling tools for the decar-bonisation of wastewater treatment plants. J. Clean. Prod. 2021, 279, 123811. [CrossRef]

18. Directive (EU) 2018/2001 of the European Parliament and the Council of 11 December 2018 on the Promotion of the Use of Energy from Renewable Sources (Recast). Available online: https:/ / eur-lex.europa.eu/legal-content/EN/TXT/?uri=CELEX\% 3A32018L2001 (accessed on 15 September 2021).

19. Seibert-Ehrling, G. Produktion, Umwandlung, Verteilung und Nutzung von Wärme auf Kläranlagen (Generation, Transformation, Distribution and Utilisation of Heat at Wastewater Treatment Plants). DWA-German Association for Water, Wastewater and Waste, Energieoptimierung auf Kläranlagen. Kassel, 12 November 2012. Available online: http:/ /www.setacon.de/index.php/ downloads.html (accessed on 9 September 2021).

20. Suter, J.; Manser, R.; Dominguez, D. Energiegrundsätze für die ARA im Kanton Bern—Beitrag zur Kantonalen Energiestrategie (Energy Principles for WWTPs in the Canton of Berne); AWA Amt für Wasser und Abfall: Bern, Switzerland, 2016.

21. Jacob, R.; Short, M.; Belusko, M.; Bruno, F. Maximising renewable gas export opportunities at wastewater treatment plants through the integration of alternate energy generation and storage options. Sci. Total Environ. 2020, 742, 140580. [CrossRef] [PubMed]

22. Picardo, A.; Soltero, V.M.; Peralta, M.E.; Chacartegui, R. District heating based on biogas from wastewater treatment plant. Energy 2019, 180, 649-664. [CrossRef] 
23. Zach, F.; Kretschmer, F.; Stoeglehner, G. Zach Integrating Energy Demand and Local Renewable Energy Sources in Smart Urban Development Zones: New Options for Climate-Friendly Resilient Urban Planning. Energies 2019, 12, 3672. [CrossRef]

24. Gruber-Glatzl, W.; Brunner, C.; Meitz, S.; Schnitzer, H. From the Wastewater Treatment Plant to the Turnstiles of Urban Water and District Heating Networks. Front. Sustain. Cities 2020, 2, 523698.

25. Stoeglehner, G.; Neugebauer, G.; Erker, S.; Narodoslawsky, M. Integrated Spatial and Energy Planning: Supporting Climate Protection and the Energy Turn with Means of Spatial Planning; Springer Briefs in Applied Sciences and Technology; Springer: Cham, Switzerland, 2016.

26. Hrdy, B. Lokale Wärme aus der Kläranlage-Energetische Bilanzierung und Integrale Bewertung Anhand des Fallbeispiels Kapfenberg (Local Heat from a WWTP_Energy Balance and Integrated Assessment Based on the Kapfenberg Case Study). Master's Thesis, University of Natural Resources and Life Sciences, Vienna, Austria, 2021.

27. Kretschmer, F.; Neugebauer, G.; Stoeglehner, G.; Ertl, T. Participation as a Key Aspect for Establishing Wastewater as a Source of Renewable Energy. Energies 2018, 11, 3232. [CrossRef]

28. OIB. OIB-Richtlinie 6. Energieeinsparung und Wärmeschutz (Energy Saving and Heat Insulation); Austrian Institute of Construction Engineering: Vienna, Austria, 2015.

29. Lindtner, S. Leitfaden Fuer Die Erstellung Eines Energiekonzeptes Kommunaler Klaeranlagen (Guideline for the Development of an Energy Concept for Municipal Wastewater Treatment Plants); Austrian Federal Ministry of Agriculture and Forestry, Environment and Water Management (BMLFUW): Vienna, Austria, 2008.

30. Sommerauer, C.; Wieland, E. Wärmerückgewinnung aus Kommunalem Abwasser und Synergiepotential für Eine Nahwärmeversorgung am Fallbeispiel Kläranlage Kapfenberg Mürz IV (Heat Recovery from Municipal Wastewater and Syn-ergy Potentials for Distric Heating at the Example of the Wastewater Treatment Plant Kapfenberg Mürz IV). Bachelor's Thesis, FH BurgenlandUniversity of Applied Sciences, Pinkafeld, Austria, 2019.

31. Wieland, E. NW-Diemlach-Excelliste mit den Gemessenen Monatsverbräuchen (Wärme) der Bestehenden Gebäude in “Riverside" (Ecxel File with Measured Monthly Heat Consumption Values of the Already Occupied Buildings in "Riverside"). Unpublished work. Municipal Energy Supply Utility Kapfenberg. 23 March 2021.

32. Austrian Standards. ÖNORM M 7140 2013. Betriebswirtschaftliche Vergleichsrechnung für Energiesysteme Nach Dynamischen Rechenmethoden (Economic Comparison Calculation of Energy Systems Based on Dynamic Calculation Methods); Austrian Standards: Vienna, Austria, 2013.

33. UBA-Environmental Protection Agency. Berechnung von Treibhausgas (THG)-Emissionen Verschiedener Energieträger (Calculation of Greenhouse Gas Emissions of Differnt Energy Carriers). Available online: https:/ / secure.umweltbundesamt.at/co2 mon/co2mon.html (accessed on 28 June 2021).

34. Kollmann, R.; Neugebauer, G.; Kretschmer, F.; Truger, B.; Kindermann, H.; Stoeglehner, G.; Ertl, T.; Narodoslawsky, M. Renewable energy from wastewater-Practical aspects of integrating a wastewater treatment plant into local energy supply concepts. $J$. Clean. Prod. 2017, 155, 119-129. [CrossRef]

35. Zöscher, A.; Fladischer, S.; Riegel, T.; Wieland, E.; Christian, S.; Gruber-Glatzl, W.; Venus, D.; Zach, F.; Hrdy, B.; Neugebauer, G.; et al. Technischer Bericht zum Projekt "Energieraumplanung Kapfenberg Südwest" (Technical Report of the Project "Integrated Spatial and Energy Plannning at Southwest Kapfenberg"); Wasserverband Mürzverband: Kapfenberg, Austria, 2021.

36. Neugebauer, G.; Stöglehner, G. Realising energy potentials from wastewater by integrating spatial and energy planning. Sustain. Sanit. Pract. 2015, 22, 15-21.

37. EAG 2021. Bundesgesetz über den Ausbau von Energie aus Erneuerbaren Quellen (Erneuerbaren-Ausbau-Gesetz-EAG) (Austrian Federal Law on the Development of Energy from Renewable Sources), StF: BGBl. I Nr. 150/2021. Available online: https: / / www.ris.bka.gv.at/GeltendeFassung.wxe?Abfrage=Bundesnormen\&Gesetzesnummer=20011619 (accessed on 15 September 2021).

38. European Commission. Renewable Energy Targets. Available online: https://ec.europa.eu/energy/topics/renewable-energy/ directive-targets-and-rules/renewable-energy-targets_en (accessed on 9 September 2021).

39. REEF 2W. Increased Renewable Energy and Energy Efficiency by Integrating, Combing and Empowering Urban Wastewater and Organic Waste Management Systems. E-Book. Interreg Central Europe. Available online: https://www.interreg-central.eu/ Content.Node/The-final-ebook-of-REEF-2W-Project.html (accessed on 9 September 2021). 